\title{
ADRB1 Gene
}

National Cancer Institute

\section{Source}

National Cancer Institute. ADRB1 Gene. NCI Thesaurus. Code C39778.

This gene plays a role in neuronal G protein-coupled receptor signal transduction that

modulates the physiological effects of epinephrine and norepinephrine. 